\title{
Evaluation of serum 25-Hydroxy vitamin D levels in children with autism Spectrum disorder
}

\author{
Ali Asghar Arastoo 1,2, Hesam Khojastehkia ${ }^{3}$, Zahra Rahimi ${ }^{4}$, Morteza Abdullatif Khafaie ${ }^{1,2}$, Syed Ahmad Hosseini ${ }^{5}$, \\ Mohammad Taghi Mansouri ${ }^{6}$, Shabnam Yosefyshad ${ }^{1}$, Maryam Abshirini ${ }^{1}$, Karimimalekabadi Noshin ${ }^{1}$ and \\ Maria Cheraghi ${ }^{1,2^{*}}$
}

\begin{abstract}
Background: Vitamin D plays an important role in etiology of Autism Spectrum Disorders (ASDs). We aimed to evaluate the serum 25 - hydroxyl vitamin D level among children with ASDs in Ahvaz city, Iran.

Methods: It was a cross-sectional study which had conducted on 62 subjects in two groups: a case group $(n=31)$ consisted of ASD children who study in especial schools; and a control group $(n=31)$ of healthy children who were selected by simple random sampling from regular schools in Ahvaz city, Iran during 2016. Maching between two groups has done regarding Socioeconomic status, type and amount of food intake, place of living and age. The levels of serum 25 - hydroxyl vitamin D were assessed in early morning means fasted state and also measured using ELISA method. Data were analyzed using Statistical Package for Social Sciences (SPSS) version 20. The significant level was considered $<0.05$.

Results: In ASD children, the average serum 25-hydroxyvitamine D level was $9.03 \pm 4.14$ ng/mg. In ASD group, 96. 8\% (30 subjects) had vitamin D deficiency. In healthy children group, average serum 25-hydroxyvitamine D level was $15.25 \pm 7.89 \mathrm{ng} / \mathrm{mg}$. Average serum 25 -hydroxyvitamine D level in intervention group was significantly lower than the control group $(P>0.001)$. Although the parents of patients in control group reported longer exposure to sun $(27.42 \mathrm{~m}$ per day against $33.06 \mathrm{~m}$ per day), no significant difference was observed between these groups in terms of exposure to sun $(P<0.05)$.
\end{abstract}

Conclusions: A significant difference was observed between serum 25-hydroxyvitamine D levels between the healthy and ASD children. It is recommended to use vitamin D supplement in children with ASDs under medical care.

Keywords: Autism, Iran, Vitamin D

\section{Introduction}

Vitamin D may play an important role in etiology of Autism Spectrum Disorders (ASDs). Vitamin D is a neuroactive steroid affecting brain development and function. It plays an essential role in myelination, which is important for connectivity in the brain. Studies have shown that decreased vitamin D levels, decreased maternal vitamin D

\footnotetext{
* Correspondence: mariacheraghi@gmail.com; Cheraghi_m@ajums.ac.ir ${ }^{1}$ Social Determinant of Health Research Center, Ahvaz Jundishapur University of Medical Sciences, Ahvaz, Iran

${ }^{2}$ Department of Public Health, Health School, Ahvaz Jundishapur University of Medical Sciences, Ahvaz, Iran

Full list of author information is available at the end of the article
}

levels during pregnancy, and decreased exposure to solar UVB might increase the risk of ASD [1].

Despite extensive studies on ASD, the etiology of this disorder is quite unknown and studies are ongoing $[2,3]$. ASD has a dominant genetic origin. However, environmental and genetic factors have interaction in the incidence of this disorder [3-5]. The results of studies have shown that in disease etiology, risk factors such as prenatal and postnatal infections [6,7], and exposure to Valproic Acid of alcohol during pregnancy [8, 9], the age of mother [10], and abnormal nutritional and metabolic factors [3] are effective. During the recent years, the incidence of ADSs has been significantly increased. In 
previous studies, the incidence of this disorder was 10 in 10,000 [11], whereas the incidence of this disorder is now estimated as 90-250 in 10,000 [12-15]. In addition, in 2010, CDC reported the incidence of autism disorder in the United States as 1 in 68 and this indicates 78\% increase in the incidence level compared with 2002 [16]. However, a part of this sudden increase is probably the result of increased awareness and better reports about autism disorder as well as improved diagnostic criteria, but the exact causes for this sudden increase should be determined in future studies [17]. Increased incidence of the disease can impose a heave financial burden on the society. It is estimated that medication costs for each patient will be 40,000 to 60,000 dollar per year [16]. During the past decades, numerous studies were conducted on the role of vitamin D in neuropsychological disorders [18-23]. The findings of these studies showed that vitamin D deficiency is one of the risk factors of evolutional neuropsychological disorders such as schizophrenia [24] and autism [19, 25-28]. However, studies on the relationship between vitamin $\mathrm{D}$ and autism in different parts of the world such as Sweden [29], Egypt [20], Saudi Arabia [30], and China [31, 32] indicate lower $25(\mathrm{OH})$ D level in patients with ASD in different ages compared with the control group. Moreover, some studies [33, 34] have shown different findings and no significant difference was observed between serum levels of vitamin D in ADS and control groups. To our knowledge few studies have been conducted in this regard in Iran and no study has been conducted in Ahvaz city, Southwestern Iran. Therefore, the present study aimed to evaluate the serum 25 - hydroxyl vitamin D level among children with ASDs in Ahvaz city, Iran.

\section{Methods}

It was a cross-sectional study which had conducted on 62 children in two groups: a case group $(n=31)$ consisted of ASD children who study in especial schools; and a control group $(n=31)$ of healthy children were selected from regular schools by using simple random sampling approach in Ahvaz city, Iran; 2016.

The two groups were matched in terms of gender, age, weight, height, head circumference, adequate breastfeeding (for at least six months), type and amount of food, socioeconomic status (the ratio of the number of family members to bedrooms was used as a measure of socioeconomic status) $[35,36]$, average income, family size, and exposure to smokers.

\section{Inclusion criteria}

Students with ASDs entered the study by confirming the diagnosis by a neurologist and based on DSM-IV criteria and obtaining written informed consent from the parents. In the control group, the informed consent of parents was among the inclusion criteria, too.

Exclusion Criteria of the study were the presence of epilepsy and the use of vitamin D supplements were considered as exclusion criteria.

\section{Clinical evaluation of patients with autism}

Diagnosis of patients with ASD based on medical experience, clinical examination, and two criteria of DSM-IV and ADI-R was confirmed by a neurology expert.

\section{Evaluation of serum 25-hydroxyvitamine D level}

The levels of serum 25 - hydroxyl vitamin D were assessed in early morning means fasted state.

An expert nurse collected $5 \mathrm{~mL}$ blood of children to measure $25(\mathrm{OH})$ D serum levels in a Blood Transfusion Center in Ahvaz city, Khuzestan, Iran. The serum samples were isolated after centrifugation and kept at $-20{ }^{\circ} \mathrm{C}$ until the laboratory assessments. The serum $25(\mathrm{OH})$ D levels were measured using the ELISA method (Euroimmun kit, Medizinische Labordiagnostika AG, Germany, EQ. 6411-9601).

According to the guidelines of the American Endocrine Association, vitamin $\mathrm{D}$ level is defined with the concentration of 25-hydroxyvitamine D3 in blood. Natural, insufficient, and deficient vitamin D levels were determined with 25-hydroxyvitamine D level lower than $20 \mathrm{ng} / \mathrm{ml}, 21-29 \mathrm{ng} / \mathrm{ml}$, and $30 \mathrm{ng} / \mathrm{ml}$, respectively [36].

All the tests in this study were performed in Nargess Laboratory in Ahvaz city under the supervision of a doctor of medical laboratory sciences. Tests were performed two times and the averaged values were used in the analyses to increase the accuracy of the results.

\section{Ethical considerations}

Prior permissions from educational authorities, school principals, and class teachers were obtained, and then written informed consent form was taken from the parents' children participate. The procedures of this study were approved by Independence Ethics Committee of Ahvaz Jundishapur University of Medical Sciences, Ahvaz, Iran (IR.AJUMS.REC.1394.199) also we have thanks to all subjects and their parents to participate in this study. Parents of children had informed consent to participate in this study.

\section{Statistical analysis}

Kolmogorov-Smirnov test was performed prior to statistical analysis to examine the normality of the variables. The results were presented in the form of statistical tables and numeric indicators. Chi-square test, t-test, and nonparametric test (Mann-Whitney $U$ test) were used to analyze the data. Variable values were expressed as frequency, mean \pm standard deviation (SD). Statistical 
calculations were performed using Statistical Package for Social Sciences version 20 (SPSS Inc., Chicago, IL, USA). For all statistical analyses, $P$ value less than 0.05 was considered as significant.

\section{Results}

The finding has shown that 31 children with ASD and 31 healthy children with age range of 5-12 years old. No significant difference was observed between two groups in terms of age $(P=0.80)$. In addition, no significant difference was observed between the mean of mother's age at the birth of the child in both groups $(P=0.28)$. Most of the subjects in the case and control groups were male (83.9 and $90.3 \%$, respectively) and no significant difference was observed in both groups in terms of gender $(P=0.45)$. Most of children in the case group were Bakhtiari (35.5\%) and in the control group were Arab (Table 1).

In ASD children, the serum 25-hydroxy vitamin D level was significantly lower than the control group $(P>0.001)$. In the ASD group, all children showed deficient or insufficient level of serum 25-hydroxy vitamin D ( $96.8 \%$ or $3.2 \%$, respectively).

In both groups, the use of direct daily sun was equal (67.74\%). No significant difference was observed between the groups in exposure to direct sun ( $\mathrm{min} /$ day) (P-0.56) (Table 2).

\section{Discussion}

Recently, the role of vitamin D deficiency is identified as an environmental risk factor for some of autoimmune disorders [37, 38]. A study by Patrick and colleagues showed that vitamin D ma influence some of social behaviors of children with autism. He emphasized that vitamin $\mathrm{D}$ is a gene activator that creates tryptophan hydroxylase enzyme. This enzyme converts tryptophan into serotonin in the brain. Therefore, a sufficient level of vitamin $\mathrm{D}$ to produce serotonin in the brain than functions as a neuron transmitter improves social behaviors by positive effects on behavior [39]. In a clinical trial study by Feng and colleagues on 37 children with autism, for three months, these children received 150,000 IU as intramuscular injection(monthly) and 400 IU orally (daily). These researchers reported that disease symptoms and behavioral checklist in children (3 years old and older) with autism improved [40]. In most of the studies conducted on ASDs and vitamin D, lower 25-hydroxyvitamine D level in children with autism was taken into consideration. Our findings showed low level 25-hydroxyvitamine $\mathrm{D}$ level in the ASD children, compared with the healthy counterparts. Testes et al. reported that the mean of serum 25-hydroxyvitamine D level in children with autism with different ethnicities was lower than the control group by $35 \mathrm{nmol} / \mathrm{L}$ [41]. Moreover, Duan et al. showed that serum 25-hydroxyvitamine $\mathrm{D}$ in patients with autism was significantly lower than the control group [31]. Bener et al. attributed some biological and lifestyle factors such as birth, kinship, body mass profile, and physical activity and 25-hydroxyvitamine D level with the incidence of autism. Their findings showed that serum 25-hydroxyvitamine D level in ASD children was lower than the control group with similar ethnicity, age, and gender $(P=0.004)$ [42]. This finding was supported by the study of Meguid et al. [20]. Saad et al. [18] reported an inverse relationship between the

Table 1 Demographic characteristics in two groups

\begin{tabular}{|c|c|c|c|}
\hline Variable & ASD N (\%) & Healthy children Number (\%) & $P$-value \\
\hline \multicolumn{4}{|l|}{ Gender } \\
\hline Male & $26(83.9)$ & $28(90.3)$ & \multirow[t]{2}{*}{$0.45^{\mathrm{a}}$} \\
\hline Female & $5(16.1)$ & $3(9.7)$ & \\
\hline \multicolumn{4}{|l|}{ Father's ethnicity } \\
\hline Fars & $6(19.4)$ & $6(19.4)$ & \multirow[t]{7}{*}{$0.51^{a}$} \\
\hline Bakhtiari & $11(35.5)$ & $7(22.6)$ & \\
\hline Arab & $10(32.3)$ & $13(41.9)$ & \\
\hline Lor & $1(3.2)$ & $3(9.7)$ & \\
\hline Tork & $2(6.5)$ & $1(3.2)$ & \\
\hline \multirow[t]{2}{*}{ Other } & $1(3.2)$ & $1(3.2)$ & \\
\hline & ASD Mean (SD) & Healthy children Mean (SD) & \\
\hline Age & $9.17(2.11)$ & $9.31(2.09)$ & $0.80^{\mathrm{b}}$ \\
\hline Height & $142.35(14.23)$ & $137.06(12.52)$ & $0.12^{b}$ \\
\hline Weight & $42.37(19.55)$ & $36.13(12.53)$ & $0.14^{\mathrm{b}}$ \\
\hline Age of mother at Childbirth & $35.52(10.90)$ & $33.22(4.60)$ & $0.28^{\mathrm{b}}$ \\
\hline
\end{tabular}

${ }^{\mathrm{a}}$ Chi-square test ${ }^{\mathrm{b}}$ Mann-Whitney test 
Table 2 Serum vitamin D level and exposure to direct sun in two groups

\begin{tabular}{llll}
\hline Variable & ASD Mean (SD) & Healthy children Mean (SD) & $P$-Value \\
\hline serum 25-hydroxyvitamine D level ng/mg & $9.03(4.14)$ & $15.25(7.89)$ & $<0.001$ \\
Time of exposure to sun & $27.42(33.14)$ & $33.06(42.94)$ & Healthy children N (\%) \\
& ASD N (\%) & $22(70.97)$ & 9.56 \\
Deficient of Vitamin D $(\leq 20 \mathrm{ng} / \mathrm{ml})$ & $30(96.77)$ & $9(29.03)$ & 0.006 \\
Insufficient of Vitamin D $(21-29 \mathrm{ng} / \mathrm{ml})$ & $1(3.22)$ & \\
\hline
\end{tabular}

averaged serum 25-hydroxyvitamine D level and severity of ASD $(P>0.001)$, which was not evaluated in our study. In another study in Saudi Arabia on comparing serum 25-hydroxyvitamine D level and MAG among 50 children with autism (5-12 years old) and 30 healthy children, a significant negative relationship was observed between serum 25-hydroxyvitamine D level and incidence of autism $(P>0.001)$ [30]. Neumeyer and colleagues reported that the ration of male children with ASD with serum 25-hydroxyvitamine $\mathrm{D}$ level lower than $80 \mathrm{nmol} / \mathrm{L}$ was higher than healthy subjects (77\% against 37\% and $p=0.02$ ). However, the results of a study by Molloy [33] and Esparham [3] in the United States showed that there is not significant relationship between serum 25-hydroxyvitamine $\mathrm{D}$ level in two groups of children with ASD and without ASD. Ugur and colleagues investigated vitamin D3 level of 54 children with autism and 54 healthy children between 3 and 8 years old in Turkey. They did not observe any significant difference $t$ vitamin D3 serum level between these two groups [35]. The results of a study by Hashemzeh and colleagues in Iran showed no significant difference between vitamin D in children with autism and healthy children. Also, no significant relationship was observed between serum vitamin $\mathrm{D}$ level and severity of the disease symptoms [34].

\section{Conclusion}

There significant difference was observed between serum 25-hydroxyvitamine D levels in two groups of this study and different studies confirm that and also there was no significant difference between two groups in time of exposure to sun. Therefore it is recommended to use vitamin D supplement in children with ASDs under medical care.

\section{Acknowledgments}

We have thanks to all subjects and their parents to participate in this study.

\section{Funding}

This study was supported by Deputy of Research in Ahvaz Jundishapur University of Medical Sciences, Ahvaz, Iran.

\section{Availability of data and materials}

Please contact author for data request.

\section{Authors' contributions}

AA: Carried out the studies. HK: Participated in concept and carried out the studies. ZR: Performed the statistical analysis and help drafted the manuscript. MK: Participated in design of the study and revised the manuscript. SAH: Participated in design of the study. SMM: Participated in concept of study. SY, Co-ordinate of the study. MA: Data collection. NKM: Data collection. MC: Participated in concept and design of the study also revising it critically for important intellectual content; and final approval of the version to be published. All authors read and approved the final manuscript.

Ethics approval and consent to participate

This study was approved by Independence Ethics Committee of Ahvaz Jundishapur University of Medical Sciences, Ahvaz, Iran (IR.AJUMS.REC.1394.199).

Consent for publication

Not applicable.

\section{Competing interests}

The authors declare that they have no competing interests.

\section{Publisher's Note}

Springer Nature remains neutral with regard to jurisdictional claims in published maps and institutional affiliations.

\section{Author details \\ ${ }^{1}$ Social Determinant of Health Research Center, Ahvaz Jundishapur University of Medical Sciences, Ahvaz, Iran. ${ }^{2}$ Department of Public Health, Health School, Ahvaz Jundishapur University of Medical Sciences, Ahvaz, Iran. ${ }^{3}$ Cherraan's college of pharmacy Dr. MGR Medical University, Chennai, India. ${ }^{4}$ Ahvaz Jundishapur University of Medical Sciences, Ahvaz, Iran. ${ }^{5}$ Department of Nutrition, School of Para Medicine, Ahvaz Jundishapur University of Medical Sciences, Ahvaz, Iran. ${ }^{6}$ Department of Anesthesiology, Columbia University Irving Medical Center, New York, NY 10032, USA.}

Received: 22 June 2018 Accepted: 14 November 2018

Published online: 17 December 2018

References

1. Fernell E, Bejerot S, Westerlund J, Miniscalco C, Simila H, Eyles D, Gillberg C, Humble MB. Autism spectrum disorder and low vitamin D at birth: a sibling control study. Molecular Autism. 2015;6:3.

2. Fahmy SF, Sabri NA, El Hamamsy MH, El Sawi M, Zaki OK. Vitamin D Intake and Sun Exposure in Autistic Children. IJPSR. 2016;7(3):1043-9.

3. Esparham AE, Smith T, Belmont JM, Michael Haden BA, Wagner LE, Evans RG, Drisko JA. Nutritional and Metabolic Biomarkers in Autism SpectrumDisorders: An Exploratory Study. Integrative Medicine. 2015; 14(2):40-53.

4. Chaste $P$, Leboyer M. Autism risk factors: genes, environment, and geneenvironment interactions. Dialogues Clin Neurosci. 2012;14:281-92.

5. Coleman M, Gillberg C. The autisms. Oxford: Oxford University; 2012.

6. Patterson PH. Maternal infection and immune involvement in autism. Trends Mol Med. 2011;17:389-94.

7. Ohkawara T, Katsuyama T, Ida-Eto M, Narita N, Narita M. Maternal viral infection during pregnancy impairs development of fetal serotonergic neurons. Brain and Development. 2015:37:88-93.

8. Meador KJ, Loring DW. Prenatal valproate exposure is associated with autism spectrum disorder and childhood autism. J Pediatr. 2013;163:924

9. Landgren M, Svensson L, Strömland K, Andersson GM. Prenatal alcohol exposure and neurodevelopmental disorders in children adopted from Eastern Europe. Pediatrics. 2010;125:e1178-85. 
10. Idring S, Magnusson C, Lundberg M, Ek M, Rai D, Svensson AC, et al. Parental age and the risk of autism spectrum disorders: findings from a Swedish population-based cohort. Int J Epidemiol. 2014;43:107-15.

11. Chakrabarti S, Fombonne E. Pervasive developmental disorders in preschool children. JAMA. 2001;285:3093-9.

12. New Zealand Guidelines Group. What does ASD look like? In a resource to help identify autism Spectrum disorder. Wellington: New Zealand Guidelines Group; 2010.

13. Kogan MD, Blumberg SJ, Schieve LA, Boyle CA, Perrin JM, Ghandour RM, Singh GK, Strickland BB, Trevathan E, van Dyck PC. Prevalence of parentreported diagnosis of autism Spectrum disorder among children in the us, 2007. Pediatrics. 2009;124:1395-403.

14. Ghanizadeh A. A preliminary study on screening prevalence of pervasive developmental disorder in schoolchildren in Iran. J Autism Dev Disord. 2008;38:759-76.

15. Baio J. Prevalence of Autism Spectrum Disorders-Autism and Developmental Disabilities Monitoring Network,14 Sites, United States, 2008 . Morbidity and mortality weekly report; Surveillance summaries, vol. 61. Atlanta: Centers for Disease Control and Prevention; 2012. p. 1-19.

16. Developmental Disabilities Monitoring Network Surveillance Year 2010 Principal Investigators; Centers for Disease Control and Prevention (CDC) Prevalence of autism spectrum disorder among children aged 8 yearsautism and developmental disabilities monitoring network, 11 sites, United States, 2010. MMWR Surveill Summ. 2014;63(2):1-21.

17. Hansen SN, Schendel DE, Parner ET. Explaining the increase in the prevalence of autism Spectrum disorders: the proportion attributable to changes in reporting practices. JAMA Pediatr. 2015;169:56-62.

18. Saad K, Abdel-Rahman AA, Elserogy YM, Al-Atram AA, Cannell JJ, Bjørklund G, et al. Vitamin D status in autism spectrum disorders and the efficacy of vitamin D supplementation in autistic children. Nutr Neurosci. 2015;19(8):346-51.

19. Kočovsk E, Fernell E, Billstedt E, Minnis H, Gillberg C. Vitamin D and autism: clinical review. Res Dev Disabil. 2012:33:1541-50.

20. Meguid NA, Hashish AF, Anwar M, Sidhom G. Reduced serum levels of 25hydroxy and 1,25-dihydroxy vitamin D in Egyptian children with autism. J Altern Complement Med. 2010;16:641-5.

21. Bener A, Hoffmann GF. Nutritional rickets among children in a sun rich country. Int J Pediatr Endocrinol. 2010;2010:410-502.

22. Holick MF, Binkley NC, Bischoff-Ferrari HA, Gordon CM, Hanley DA, Heaney $\mathrm{RP}$, et al. Evaluation, treatment, and prevention of vitamin D deficiency: an Endocrine Society clinical practice guideline. J Clin Endocrinol Metab. 2011; 96:1911-30

23. Eyles DW, Burne TH, McGrath JJ. Vitamin D, effects on brain development, adult brain function and the links between low levels of vitamin $D$ and neuropsychiatric disease. Front Neuroendocrinol. 2013;34:47-64.

24. McGrath J. Is it time to trial vitamin D supplements for the prevention of schizophrenia? Acta Psychiatr Scand. 2010;121:321-4.

25. Cannell JJ. Autism and vitamin D. Med Hypotheses. 2008;70:750-9.

26. Bakare MO, Munir KM, Kinney DK. Association of hypomelanotic skin disorders with autism: links to possible etiologic role of vitamin-D levels in autism? Hypothesis (Tor), vol. 9; 2011. p. e2.

27. Cannell JJ, Grant WB. What is the role of vitamin D in autism? Dermatoendocrinol. 2013;5:199-204.

28. Gentile I, Zappulo E, Militerni R, Pascotto A, Borgia G, Bravaccio C. Etiopathogenesis of autism spectrum disorders: fitting the pieces of the puzzle together. Med Hypotheses. 2013;81:26-35.

29. Humble MB, Gustafsson S, Bejerot S. Low serum levels of 25-hydroxyvitamin D (25-OHD) among psychiatric out-patients in Sweden: relations with season, age, ethnic origin and psychiatric diagnosis. J Steroid Biochem Mol Biol. 2010;121(1-2):467-70.

30. Mostafa GA, Al-Ayadhi LY. Reduced serum concentrations of 25-hydroxy vitamin $D$ in children with autism: relation to autoimmunity. $J$ Neuroinflammation. 2012;17:201.

31. Duan $X Y$, Jia FY, Jiang HY. Relationship between vitamin $D$ and autism spectrum disorder. Zhongguo Dang Dai Er Ke Za Zhi. 2013;15:698-702.

32. Gong ZL, Luo CM, Wang L, Shen L, Wei F, Tong RJ, et al. Serum 25hydroxyvitamin $D$ levels in Chinese children with autism spectrum disorders. Neuroreport. 2014;25:23-7.

33. Molloy CA, Kalkwarf HJ, Manning-Courtney P, Mills JL, Hediger ML. Plasma $25(\mathrm{OH}) \mathrm{D}$ concentration in children with autism spectrum disorder. Developmental Medicine \& Child Neurology. 2010;52:969-71.
34. Hashemzadeh M, Moharreri F, Soltanifar A. Comparative study of vitamin D levels in children with autism spectrum disorder and normal children: a case-control study. Journal of Fundamentals of Mental Health. 2015 July-Aug;17(4):197-201.

35. C. Ugur, C.K. Gürkan. Serum vitamin D and folate levels in children with autism spectrum disorders. Research in Autism Spectrum Disorders. 2014;8: 1641-1647.

36. Rossignol DA, Frye RE. Mitochondrial dysfunction in autism spectrum disorders: a systematic review and meta-analysis. Mol Psychiatry. 2012;17(3): 290-314.

37. Zhang HL, Wu J. Role of vitamin D in immune responses and autoimmune diseases, with emphasis on its role in multiple sclerosis. Neurosci Bull. 2010; 26:445-54.

38. Hamza RT, Awwad KS, Ali MK, Hamed Al. Reduced serum concentrations of 25-hydroxy vitamin D in Egyptian patients with systemic lupus erythematosus: relation to disease activity. Med Sci Monit. 2011;17:CR711-8.

39. Patrck RP, Ames BN. Vitamin D hormone regulates serotonin synthesis.Part1: relevance for autism. FASEB J. 2014;28(6):2398-413. https://doi.org/10.1096/ FJ.13-246546.

40. Feng J, Shan L, Du L, Wang B, Li H, Wang W, Wang T, Dong H, Yue X, Xu Z, et al. Clinical improvement following vitamin D3 supplementation in autism Spectrum disorder. Nutr Neurosci. 2016;20(5):284-90.

41. Tostes MHFDS, Polonini HC, Gattaz WF, Raposo NRB, Baptista EB. Low serum levels of 25-hydroxyvitamin D (25-OHD) in children with autism. Trends Psychiatry Psychother. 2012;34:161-3.

42. Bener A, Khattab AO, Al-Dabbagh MM. Is high prevalence of vitamin D deficiency evidence for autism disorder? In a highly endogamous population. J Pediatr Neurosci. 2014;9:227-33.

\section{Ready to submit your research? Choose BMC and benefit from:}

- fast, convenient online submission

- thorough peer review by experienced researchers in your field

- rapid publication on acceptance

- support for research data, including large and complex data types

- gold Open Access which fosters wider collaboration and increased citations

- maximum visibility for your research: over $100 \mathrm{M}$ website views per year

At $\mathrm{BMC}$, research is always in progress.

Learn more biomedcentral.com/submission 